\title{
KOMPETENSI PROFESIONAL GURU SEKOLAH MENENGAH PERTAMA KABUPATEN KENDAL
}

\author{
Sofyan Anif, Sutama, Harun Joko Prayitno, Sukartono \\ Universitas Muhammadiyah Surakarta \\ Email: Sut197@ums.ac.id
}

\begin{abstract}
The teacher has a vital and fundamental role as an agent of change in helping and guiding students in the process of changing from not knowing to knowing, not understanding to understanding, not mastering to mastering and so on. Such circumstances indicate that it is appropriate to improve the professional competence of teachers. The purpose of this study is to describe the professional competence of junior high school teachers. The research method used is qualitative with data collection techniques through observation, interviews and documentation. Data validation is done through triangulation, with analysis of data flow methods with the process: data collection, data reduction, then presented, followed by conclusions and verification. The results showed that the professional competence of teachers showed an average of 1.33 in poor condition. Specifically if related to teacher perceptions, it can be seen from the competencies about personality and competencies about carrying out tasks. Perspesi regarding personality is related to work discipline, work morality, loyalty, responsibility and human relations, while the perception of competence in carrying out tasks is related to work suitability and fluency in carrying out tasks.
\end{abstract}

Keywords: competence; professional; teacher;policy

\begin{abstract}
Abtsrak. Guru memiliki peran sebagai agent of change yang sangat vital dan fundamental dalam membantu dan memandu siswa dalam proses terjadinya perubahan dari tidak tahu menjadi tahu, tidak mengerti menjadi mengerti, tidak menguasai menjadi menguasai dan sebagainya. Keadaan demikian menunjukkan bahwa sangatlah tepat meningkatkan kompetensi profesional guru. Tujuan penelitian ini untuk mendeskripsikan kompetensi profesional guru Sekolah Menengah Pertama. Metode penelitian yang digunakan kualitatif dengan teknik pengambilan data melalui observasi, wawancara dan dokumentasi. Validasi data dilakukan melalui triangulasi, dengan analisis data metode alir dengan proses: pengumpulan data, reduksi data, selanjutnya disajikan yang dilanjutkan dengan penarikan simpulan dan verifikasi. Hasil penelitian menunjukkan bahwa kompetensi profesional guru menunjukkan rata-rata 1,33 berada dalam kondisi tidak baik. Secara khusus jika dihubungkan dengan persepsi guru, dapat dilihat dari kompetensi tentang kepribadian dan kompetensi tentang melaksanakan tugas. Perspesi tentang kepribadian berhubungan dengan disiplin kerja, moralitas kerja, loyalitas, tanggung jawab dan hubungan manusiawi, sedangkan persepsi tentang kompetensi dalam melaksanakan tugas berhubungan dengan kesesuai kerja dan kelancaran melaksanakan tugas.
\end{abstract}

Kata kunci: kompetensi; profesional; guru; kebijakan

\section{Pendahuluan}

Pendidikan berkualitas telah menjadi kebutuhan seluruh bangsa, tidak terkecuali bangsa Indonesia, sehingga berbagai upaya telah, sedang dan akan dilakukan pemerintah untuk mewujudkan pendidikan yang 
didambakan seluruh masyarakat. Upayaupaya tersebut terkait dengan peningkatan kompetensi profesional guru yang merupakan key person in the classroom sebagaimana dipersyaratkan Undang-undang Nomor 14 Tahun 2005 tentang Guru dan Dosen dan Permendiknas Nomor 16 Tahun 2007 tentang Kompetensi Guru, yang meliputi paedagogik, kepribadian, sosial dan profesional. Guru profesional yang tercermin dari perilaku dalam melaksanakan tugasnya sangat dibutuhkan karena guru memiliki peran sangat strategis dan sentral dalam proses peningkatan mutu pendidikan. Guru sesuai dengan tugas dan fungsinya harus senantiasa berada di garis terdepan dalam pelaksanaan kegiatan pembelajaran di sekolah. (Agus Dharma, 2009:177). Sumarna Surapranata (2009:210) mengemukakan juga bahwa bahwa "guru merupakan komponen yang sangat menentukan sebagai ujung tombak peningkatan mutu pendidikan. Guru memiliki peran yang sangat sentral dan strategis dalam peningkatan mutu pendidikan". Kurikulum, sarana pendidikan, maupun penunjang lain, tanpa guru yang profesional dan kompeten, hasil pembelajaran yang berkualitas dan optimal akan sulit untuk diwujudkan.

Peningkatan kompetensi profesional guru telah dan masih terus dilakukan, tetapi permasalahan yang masih muncul adalah "apakah saat ini guru sudah benar-benar profesional sebagaimana dipersyaratkan dalam Permendiknas Nomor 16 Tahun 2007 tentang Kompetensi Guru? dan apakah model pelatihan guru yang selama ini dilakukan sudah tepat? Mutu suatu program pendidikan selain bergantung kepada mutu program juga bergantung kepada guru yang handal yang tentu saja harus ada kegiatan pelatihan peningkatan kompetensi profesional guru itu sendiri. Guru handal dapat dihasilkan dari pelatihan peningkatan kompetensi profesional, rencana-rencana sekolah maupun kurikulum sekolah yang dilaksanakan dengan sebaikbaiknya, sehingga tercapai mutu sekolah yang diharapkan. Apabila telah tersusun suatu rencana pengembangan sekolah atau telah tersedia kurikulum sekolah yang baik, tetapi gurunya tidak memahami rencana dan kurikulum sekolah tersebut, maka semua rencana dan kurikulum tersebut tidak akan dapat dijalankan. Persyaratan adanya guru yang handal dalam suatu sekolah adalah suatu syarat yang mutlak.

Berdasarkan data hasil pemetaan kompetensi guru Sekolah Menengah Pertama (SMP) di Kabupaten Kendal menunjukkan bahwa rata-rata guru SMP di Kabupaten Kendalmemiliki nilai tes yang belum mencapai standar yang ditetapkan. Dari 56 soal yang diujikan jawaban benar paling tinggi adalah 34 atau $60,71 \%$ dan salah mencapai 41 soal atau $73,21 \%$, dengan rata-rata benar sekitar 24,76 butir atau 44,21\% (kurang sekali) berdasarkan kategori yaitu: $>75 \%$ (baik sekali), 65\%75\% (baik), 55\%-64\% (sedang), 45\%-54\% (kurang) dan $<45 \%$ (kurang sekali), sehingga kompetensi profesional guru tersebut masih rendah. Selain itu pula berdasarkan data hasil supervisi pembelajaran Lembaga Penjaminan Mutu Pendidikan (LPMP) Jawa Tengah Tahun 2018 menunjukkan bahwa guru SMP masih lemah dalam membuat Rencana Pelaksanaan Pembelajaran (RPP), melaksanakan dan evaluasi pembelajaran sertamenyusun program tindak lanjut. Guru profesional memiliki kompetensi dengan berbagai kapasitasnya sebagai pendidik. Guru profesional memiliki pengalaman mengajar, kapasitas intelektual, moral, keimanan, ketaqwaan, disiplin, tanggungjawab, wawasan kependidikan yang luas, kemampuan manajerial, trampil, kreatif, memiliki keterbukaan profesional dalam memahami potensi, karakteristik dan masalah perkembangan peserta didik, mampu mengembangkan rencana studi dan karir peserta didik serta memiliki kemampuan meneliti dan mengembangkan kurikulum. Guru profesional adalah orang yang memiliki kemampuan dan keahlian khusus dalam bidang keguruan, sehingga mampu melakukan tugas dan fungsinya sebagai guru dengan kemampuan maksimal. Guru profesional adalah orang yang terdidik dan terlatih dengan baik, serta memiliki pengalaman yang kaya di 
bidangnya.

Hasil penelitian yang dilakukan Theeb, Muhaidat dan Al-Zboon (2013) menunjukkan bahwa "pelatihan kompetensi profesional guru menjadi hal yang utama. Pelatihan yang diberikan harus bisa mendorong dan menciptakan guru profesional". Dian Anugaerahwati (2010) menunjukkan bahwa "betapa pentingnya mengembangkan profesionalisme. Para guru berusaha meningkatkan kompetensi profesional melalui seminar, lokakarya, dan mereka juga sering diundang menjadi nara sumber dalam pelatihan di sekolah lain dan bahkan terkadang dalam tingkat propinsi." William Sanchez. (2014) menunjukkan bahwa "pengalaman dalam kehidupan sosial akan mampu membangun karakter guru yang profesional". Berdasarkan hasil-hasil kajian tersebut, maka kompetensi profesional merupakan sesuatu yang kompleks dalam meraihnya, namun melalui strategi yang dilaksanakan secara tepat dan efisien perwujudan sosok guru yang memiliki kompetensi profesional dapat dicapai secara optimal dengan berbasis kebijakan. Oleh karena itu fokus kajian artikel ini lebih mengedepankan kompetensi profesional bagi guru SMP berbasis kebijakan di Kabupaten Kendal.

Kompetensi profesional guru adalah "kompetensi yang ditunjukkan guru dalam melaksanakan peran dan fungsinya sebagai profesi seorang guru dengan penuh tanggung jawab, dedikasi, loyalitas dan kesungguhan dengan didasarkan pada kompetensi keguruan yang dimiliki." (Achmad Sanusi, 2011:2). Kemudian Muhammad Surya (2013:138) mengemukakan kompetensi profesional adalah "berbagai kemampuan yang diperlukan agar dapat mewujudkan dirinya sebagai guru profesional, yang meliputi kepakaran atau keahlian dalam bidangnya yaitu penguasaan bahan yang harus diajarkannya beserta metodenya, sehingga dapat membimbing peseta didik mencapai standar kompetensi yang telah ditentukan." Dengan demikian kompetensi profesional guru merupakan kemampuan penguasaan materi pelajaran secara luas dan mendalam, sehingga memungkinkan guru untuk membimbing peserta didik memenuhi standar kompetensi sesuai dengan Standar Nasional Pendidikan. Kompetensi guru berhubungan dengan kemampuan yang ditunjukkan seorang guru ketika melaksanakan peran dan fungsinya sebagai guru dalam proses pembelajaran di dalam kelas dengan berlandaskan kepada tanggung jawab, dedikasi, loyalitas dan kesungguhan dengan diimbangi oleh seluruh potensi yang dimiliki. Guru yang memiliki kompetensi akan bekerja melaksanakan fungsi dan tujuan sekolah khususnya dan tujuan pendidikan umumnya, sehingga dituntut untuk memiliki sejumlah karakteristik yang diharapkan.

Syamsu Rizal (2012:10) mengemukakan bebarapa ciri guru yang kompeten, yaitu: "dia senantiasa bercita-cita untuk berada atau berkinerja mendekati standar ideal; selalu berusaha untuk memperbaiki dirinya melalui pengalaman belajar, baik belajar secara formal yang terstruktur dengan gelar yang lebih tinggi misalnya, atau belajar dalam arti dari pengalaman-pengalaman yang lebih terarah; dan seorang guru yang profesionalisme tinggi itu artinya dia memiliki kebanggaan profesi". Selanjutnya Muhammad Uzer Usman (2012:67) mengemukakan bahwa "guru yang profesional harus memiliki beberapa kompetensi, yaitu: menguasai landasan kependidikan; menguasai bahan pengajaran; melaksanakan program pengajaran; dan menilai hasil dan proses belajar mengajar yang telah dilaksanakan". Lebih lanjut dan secara khusus Rochman Natawidjaja (2012:3-4) merinci sepuluh kemampuan dasar guru yang apabila memiliki kemampuan-kemampuan tersebut menunjukkan kompetensi, yaitu: "penguasaan bahan pelajaran beserta konsepkonsep dasar keilmuannya; pengelolaan program belajar mengajar; pengelolaan kelas; penggunaan media dan sumber pembelajaran; penguasaan landasan-landasan kependidikan; pengelolaan interaksi belajar mengajar; penilaian prestasi siswa; pengenalan fungsi dan program bimbingan dan penyuluhan; 
pengenalan dan penyelenggaraan administrasi sekolah; dan pemahaman prinsip-prinsip dan pemanfaatan hasil penelitian pendidikan untuk kepentingan mutu pengajaran". Kesepuluh kemampuan dasar guru sebagai standar komptensi guru tersebut, telah diterapkan dalam rangka pengembangan program kurikulum pendidikan dan dalam mengamati tingkat kemampuan guru dewasa ini. Berdasarkan Permendiknas Nomor 16 Tahun 2007 dijelaskan tentang Standar Kualifikasi Akademik dan Kompetensi Guru guna menunjang kompetensi profesional guru, yaitu: menguasai materi, struktur, konsep, dan pola pikir keilmuan yang mendukung mata pelajaran yang diampu, menguasai standar kompetensi dan kompetensi dasar mata pelajaran yang diampu, mengembangkan materi pembelajaran yang diampu secara kreatif, mengembangkan keprofesionalan secara berkelanjutan dengan melakukan tindakan reflektif dan memanfaatkan teknologi informasi dan komunikasi untuk mengembangkan profesi.

Jika dilihat dari dimensi kompetensi profesional guru, maka faktor-faktor yang dikategorikan mempengaruhi kompetensi profesional guru menurut Djam'an Satori (2010:45) adalah: "latar belakang pendidikan; kesesuaian tugas mengajar dengan latar belakang pendidikan;jenis penataran/pelatihan yang telah diikuti; peranserta dalam kegiatan MGMP/MGBS dan beban mengajar". Sistem dan bentuk peningkatan kompetensi guru yang harus diterapkan hendaknya dilakukan dengan berupa bantuan dan pelayanan. Sistem bantuan yang dimaksud merupakan proses peningkatan yang dilakukan dengan cara para pembina membantu para guru untuk mampu melakukan tugas dan tanggungjawabnya dengan baik, misalnya dengan cara memberi contoh atau mendemonstrasikannya. Sistem pelayanan yang dimaksud dalam peningkatan merupakan proses yang dilakukan dengan cara kepala sekolah menerima dan berupaya membantu guru apabila dihadapkan pada berbagai permasalahan yang ditemui di sekolahnya. Bantuan dan layanan yang diberikan oleh kepala sekolah merupakan kunci dari keberhasilan guru dalam menjalankan tugas dan tanggung jawabnya sebagai pengajar secara profesional. Keadaan ini tentunya dapat diwujudkan apabila dalam pelaksanaannya mampu dikelola dengan baik dan terdapat adanya sistem kerjasama antara guru dan kepala sekolah.

\section{Metode Penelitian}

Penelitian ini dilaksanakan di SMPN yang menjadi tanggung jawab Dinas Pendidikan Kabupaten Kendal. Pengambilan data dilakukan pada bulan Januari 2015. Metode penelitian yang digunakan adalah metode deskriptif kualitatif, sebagaimana dikemukakan Danim (2017:187) bahwa penelitian deskriptif kualitatif bersifat deskriptif, di mana data yang dikumpulkan berbentuk kata-kata, gambar dan bukan angka-angka, meskipun ada angka-angka tetapi sifatnya sebagai penunjang. Teknik pengumpulan data dilakukan oleh peneliti sendiri (peneliti sebagai instrumen). Adapun untuk mengumpulkan data digunakan beberapa metode yaitu: observasi, wawancara, dokumentasi dan angket. Hal itu untuk memperoleh data penelitian secara lengkap, menyeluruh dan komprehensif.

Observasi yang digunakan dalam penelitian ini ialah observasi partisipasi aktif. Hal ini dilakukan dengan tujuan agar peneliti dapat mempelajari dan memahami perilaku orang-orang yang terlibat di dalamnya dengan jalan berpartisipasi aktif bersama para partisipan. Dalam melakukan penelitian, peneliti selalu mengendalikan diri sendiri agar hasil pengamatan yang dilakukan tidak dipengaruhiolehlatarbelakangdankebudayaan peneliti. Dengan demikian pengamatan yang dilakukan seluas mungkin dan catatan hasil observasi selengkap mungkin. Wawancara ialah percakapan yang bertujuan, biasanya antara dua orang (tetapi kadang-kadang lebih) yang diarahkan oleh salah satu seorang dengan maksud memperoleh keterangan (Munandir, 2010:78). Senada dengan pernyataan tersebut, Nasution (2010:73) menyebutkan bahwa 
tujuan wawancara ialah untuk mengetahui apa yang terkandung dalam pikiran dan hati orang lain, bagaimana pandangannya tentang dunia, yaitu hal-hal yang tidak dapat kita ketahui melalui observasi. Penelitian ini menggunakan teknik wawancara sesuai yang disarankan Sanafiah Faisal (2010:61-62) agar peneliti dapat menggali tidak saja apa yang diketahui dan dialami subyek yang diteliti, tetapi juga yang tersembunyi jauh di dalam diri subyek penelitian dan apa yang ditanyakan kepada informan bisa mencakup masa lampau, sekarang dan masa yang akan datang. Sebelum pelaksanaan wawancara, peneliti terlebih dahulu melakukan kesepakatan dengan informan mengenai kapan, dimana, pukul berapa dapat dilakukan wawancara.

Untuk melengkapi data wawancara dan observasi, peneliti menambahkan bahan-bahan dokumentasi. Bahan-bahan dokumentasi tersebut antara lain berupa suratsurat, gambar/foto, atau catatan-catatan lain yang berhubungan dengan fokus penelitian. Adapun salah satu keuntungan penggunaan bahan-bahan ini karena telah ada, telah tersedia, dan siap pakai. Peneliti menggunakan teknik dokumentasi karena memiliki sejumlah alasan. Pelaksanaan pengumpulan data dilakukan melalui beberapa tahap, yaitu orientasi, eksplorasi, dan member check. Pengecekan atau pemeriksaan data dilakukan dengan menggunakan kriteria-kriteria tertentu. Menurut Lexy J. Moleong (2007:56) kriteria tersebut meliputi: kredibilitas, dependabilitas dan konfirmabilitas.Untuk penelitian kualitatif pada hakekatnya tidak ada satu cara tertentu yang dapat diikuti untuk dijadikan pedoman dalam menganalisis data, sehingga oleh peneliti mencaris endiri metode yang dirasakan lebih cocok dengan masalah penelitiannya. Hadisubroto (2013:20) mengemukakan bahwa dalam analisis data kuantitaif metodenya sudah jelas dan pasti, sedangkan untuk analisis data kualitatif metode seperti itu belum ada. Penelitilah yang berkewajiban menciptakannya sendiri. Oleh sebab itu ketajaman dan ketepatan analisis data kualitatif sangat tergantung kepada ketajaman melihat data oleh peneliti serta kekayaan pengalaman dan pengetahuan yang telah dimiliki peneliti. Berdasarkan hal tersebut, maka dengan proses penyusunan data, dapat ditafsirkan dan diketahui maknanya. Adapun langkah-langkah dalam pengolahan dan analisis data adalah sebagai berikut.

1. Setiap data yang dikumpulkan peneliti, mengandung hal-hal yang berkaitan dengan informasi dan masalah yang berbeda. Oleh karena itu, maka langkah pertama yang digunakan adalah menentukan fokus penelitian tertentu.

2. Mengorganisasikan data menurut masingmasing fokus dari penelitian. diperoleh melalui wawancara dan observasi.

3. Data yang telah terorganisir dianalisis, berdasarkan suatu konsensus jugment dengan merujuk kepada landasan teoritis yang telah dikemukakan, maka data yang peneliti lakukan adalah dengan mengelompokan data berdasarkan pertanyaan penelitian yang diperoleh dari berbagai informan. Kemudian, data yang diperoleh disimpulkan menjadi satu kedalaman yang bermakna.

4. Memberikan tafsiran tentang apa yang diperoleh dari setiap analisis pertanyaan penelitian dan menarik kesimpulan secara inferensial dengan melihat kesamaan dan perbedaan jawaban pertanyaan kemudian dikaitkan dengan teori.

5. Mengingat penelitian ini bersifat diagnostik, maka pada langkah akhir diajukan rekomendasi berupa beberapa pemikiran tentang apa yang seharusnya dilakukan oleh Dinas Pendidikan Kabupaten Kendal.

Kegiatan penelitian diawali dengan pengumpulan data. Kemudian data yang telah diperoleh dipilih sesuai dengan kebutuhan penelitian untuk selanjutnya disajikan yang dilanjutkan dengan penarikan simpulan dan verifikasi. Kegiatan pemilihan, penyajian dan pengambilan simpulan serta veifikasi disebut sebagai kegiatan analisis data berdasarkan pengumpulan data yang telah dilakukan. 


\section{Hasil Penelitian dan Pembahasan}

Kompetensi profesional guru SMP di Kabupaten Kendal jika dibandingkan dengan kompetensi pedagogik, sosial yang dimiliki peserta pelatihan serta perubahan perilaku yang ditampilkan dapat dilihat pada tabel berikut.

Tabel 1 Kompetensi Profesional Guru SMP di Kabupaten Kendal

\begin{tabular}{clcc}
\hline No. & \multicolumn{1}{c}{ Indikator } & Skor Rata-rata & Ket. \\
\hline 1 & Kompetensi pedagogik yang dimiliki guru & 1,67 & Tidak Baik \\
2 & Kompetensi profesional yang dimiliki guru & 1,33 & Tidak Baik \\
3 & Kompetensi sosial yang dimiliki peserta guru & 1,46 & Tidak Baik \\
4 & Perubahan perilaku yang ditampilkan guru & 1,42 & Tidak Baik \\
\hline & Skor Rata-rata Total & 1,47 & Tidak Baik \\
\hline
\end{tabular}

Berdasarkan tabel tersebut menunjukkan bahwa secara keseluruhan indikator yang berkaitan dengan kompetensi profesional guru SMP berada dalam rata-rata 1,47 (tidak baik). Semua indikator memiliki nilai rata-rata tidak baik, sehingga hal tersebut menunjukkan titik lemahnya kompetensi yang dimiliki. Kepala sekolah mengungkapkan bahwa "kompetensi guru selain berkaitan dengan kompetensi pedagogik, profesional, sosial dan perubahan perilaku yang ditampilkan, maka agar lebih profesional hendaknya guru juga memiliki kompetensi yang berkaitan dengan kepribadian, penguasaan substansi materi, pembuatan PTK, peningkatan pemahaman PKB, penguasaan SKL dan penjabarannya". (Wawancara, 22 Januari 2015). Sementara itu guru juga mengatakan bahwa "kompetensi yang harus dimiliki guru pedagogik, kepribadian, sosial, terampil menyusun RPP, soal, dll, mampu mengimplementasikan hasil pelatihan ke sekolah masing-masing, mampu mengimbaskan di MGMP sekolah, memahami kurikulum 2013 dan melaksanakan PTK". (Wawancara, 22 Januari 2015). Melihat kompetensi yang ditawarkan sangat lengkap yang harus dimiliki guru dalam melaksanakan tugasnya, tatapi hasil penelitian masih menunjukkan bahwa empat kompetensi yang dimiliki guru masih lemah (berada dalam kualifikasi tidak baik).

Secara khusus jika dihubungkan dengan persepsi kompetensi profesional guru, dapat dilihat dari kompetensi tentang kepribadian dan kompetensi tentang melaksanakan tugas. Perspesi tentang kepribadian berhubungan dengan disiplin kerja, moralitas kerja, loyalitas, tanggung jawab dan hubungan manusiawi, sedangkan persepsi tentang kompetensi dalam melaksanakan tugas berhubungan dengan kesesuai kerja dan kelancaran melaksanakan tugas.Untuk lebih jelasnya aspek-aspek yang berhubungan dengan persepsi tentang kompetensi profesional tersebut dapat dijelaskan sebagai berikut.

\section{Persepsi Tentang Kepribadian}

a. Disiplin Kerja. Seorang guru yang memiliki persepsi tentang kedisiplinan yaitu dibuktikan dengan kegiatannya yang dapat meningkatkan kemampuan dalam bertindak, berfikir dan bekerja secara aktif serta kreatif. Guru yang berdisiplin mengupayakan untuk dapat menyelidiki, meneliti, bertanya dan mencoba, sehingga kemampuan siswa meningkat. Jadi yang dikatakan sebagai disiplin kerja adalah suatu perbuatan yang mentaati, mematuhi dan tertib akan aturan, norma dan kaidah-kaidah yang berlaku, baik di masyarakat maupun di sekolah. Salah satu bentuk kongkrit yang dapat ditunjukkan guru sehubungan dengan aspek kedisiplinan kerjanya adalah dalam pemanfaatan jam kerja dan kepatuhan terhadap aturan. 
b. Moralitas Kerja. Moralitas kerja berhubungan dengan aspek-aspek perilaku yang ditampilkan guru dalam melaksanakan tugas dengan berdasarkan pada norma dan aturan yang berlaku. Seorang guru harus menjaga moralnya agar dirinya tetap berwibawa, disegani dan dicontoh oleh personil lain yang berada di sekolah tersebut.Moralitas guru dapat terjadi karena kepribadian guru tersebut maupun lingkungan yang mempengaruhinya. Moralitas terwujud secara internal dan eksternal. Internal jelas merupakan moralitas dasar guru untuk melakukan suatu perbuatan yang menurutnya baik dan tidak baik, sedangkan ekternal berasal dari lingkungan dan aturan yang telah ditetapkan, baik di sekolah maupun di masyarakat.

c. Loyalitas. Seorang guru sudah barang tentu harus memiliki loyalitas yang tinggi dalam melaksanakan tugas dan tanggungannya, sehingga kinerja benar-benar terlaksana dengan baik, baik tujuan institusi maupun tujuan kerja. Loyalitas bagi guru merupakan syarat utama dalam memajukan kinerja di sekolah maupun di masyarakat. Untuk itulah dengan adanya loyalitas yang dimiliki semua kebijakan, kebijaksanaan dan keputusan pemerintah yang telah ditetapkan dapat dilaksanakan dengan baik. Loyal adalah suatu perilaku taat dan patuh terhadap suatu kebijakan, peraturan dan keputusan serta menjalankan tugas dan tanggung jawabnya sesuai dengan tujuan yang telah ditetapkan. Salah satu bukti loyalitas bagi guru adalah adanya kesadaran, kemauan dan keputusan dalam melaksanakan semua peraturan yang berlaku baik tertulis maupun tidak tertulis. Artinya bahwa seorang guru yang bertugas melaksanakan tugas di sekolah maupun di masyarakat akan hormat, patuh dan disiplin dalam melaksanakan peraturan. Seorang guru yang loyal adalah guru yang patuh melaksanakan isi peraturan yang tersirat maupun yang tidak tersirat baik berupa kebijakan dan kebijaksanaan yang ditetapkan sekolah tersebut. Loyalitas seorang guru merupakan kesetiaan yang dimiliki dalam melaksanakan tugas dantanggungjawabdenganjanjiyang telah diutarakan sewaktu diangkat sumpah menjadi guru, yaitu setiap terhadap idiologi Negara, konstitusi Negara, peraturan dan perundangundangan negara dan kebijakan dan kebijaksanaan pemerintah. Seorang guru yang memiliki loyalitas dalam melaksanakan tugas dan fungsi di sekolah juga didasari oleh pengabdiannya terhadap lembaga sesuai dengan aturan yang telah ditetapkan dengan tetap menyeimbangkan kepentingan lembaga dengan kepentingan pribadi.

d. Tanggung jawab. Seorang guru memiliki banyak tugas dan tanggung jawab, baik terikat oleh dinas maupun di luar dinas, atau dalam bentuk pengabdian, apabila dikelompokkan terdapat tiga jenis tugas dan tanggung jawab guru, yaitu dalam bidang profesi, kemanusiaan dan kemasyarakatan. Setiap tugas dan tanggungjawab tersebutmemerlukan sejumlah kemampuan dan setiap kemampuan dapat dijabarkan lagi dalam kemampuan yang lebih khusus, antara lain: tanggung jawab moral, yaitu setiap guru harus memiliki kemampuan dalam bentuk menghayati perilaku dan etika yang sesuai dengan moral Pancasila dan mengamalkannya dalam kehidupan sehari-hari.Tanggung 
jawab dalam proses pembelajaran di sekolah yaitu setiap guru harus menguasai cara pembelajaran yang tepat, mampu membuat persiapan mengajar, mampu dan memahami kurikulum dengan baik, mampu mengajar di kelas, mampu menjadi model bagi para siswa, mampu memberikan nasehat, menguasai teknik-teknik pemberian bimbingan dan layanan, mampu membuat dan melaksanakan evaluasi serta lainnya.Tanggung jawab dalam bidang kemasyarakat yaitu turut serta mensukseskan pembangunan dalam masyarakat, untuk itu guru harus mampu dalam membimbing, mengabdi dan melayani masyarakat. Tanggung jawab dalam bidang keilmuan yaitu guru selaku ilmuwan bertanggung jawab dan turut serta memajukan ilmu, terutama yang telah menjadi spesialisasinya dengan melaksanakan penelitian dan pengabdian. Tanggung jawab yang diemban tersebut sebagai suatu ketetapan yang telah diputuskan, baik oleh pihak sekolah maupun pemerintah. Untuk itulah dalam implementasinya, tanggung jawab bagi guru adalah menerima hasil keputusan tersebut dan melaksanakan hasil keputusan dengan sebaikbaiknya.

e. Hubungan Manusiawi. Hubungan manusia merupakan hubungan yang bersifat antar personal, artinya hubungan yang ditunjukkan guru dengan orang lain yang berada di lingkungannya, baik peserta didik, sesama guru maupun dengan kepala sekolah. Hubunganmanusiawiadalah bagaimana guru berkomunikasi dengan orang lain yang mengarah kepada upaya pencapaian tujuan pendidikan di sekolah. Kualitas komunikasi tersebut dapat terlihat dari struktur atau objek yang diajak berkomunikasi, misalnya bagaimana seorang guru berkomunikasi dengan siswa, sesama rekan kerja maupun dengan kepala sekolah. Ditinjau dari sudut kepentingan jelas materi yang dikomunikasikan akan sangat berbeda.

\section{Persepsi Tentang Kompetensi dalam Melaksanakan Tugas}

a. Kesesuaian Kerja. Kesesuaian kerja berhubungan dengan keselarasan antara kemampuan yang dimiliki guru dengan tugas yang harus dilaksanakan. Seorang guru yang kurang memiliki kesesuaian akan kemampuan dengan tugas yang harus kejakan jelas akan mengalami hambatan dan lama dalam melaksanakan tugasnya. Keadaan ini jelas akan menjadi faktor penghambat terhadap pencapaian tujuan pendidikan di sekolah. Untuk itulah jelas bahwa dalam tahap awal agar terjadi kesesuaian kerja kualifikasi pendidikan dan pengalaman harus menjadi perioritas utama dalam menentukan layak tidaknya seorang guru untuk melaksanakan tugas di sekolah.

b. Kelancaran Kerja. Kelancaran kerja berhubungan dengan tidak adanya hambatan yang berarti dalam melaksanakan tugas. Kelancaran tersebut dapat disebabkan oleh beberapa faktor, misalnya sesuainya kemampuan dengan kerja yang harus dilaksanakan, minat dan bakat yang dimiliki, dukungan fasilitas yang ada atau bimbingan dan arahan dari pimpinan sekolah. Kelancaran kerja yang dirasakan seorang guru dalam melaksanakan tugasnya jelas pada akhirnya akan memberikan persepsi yang baik bagi guru dalam melaksanakan tugas mengajarnya di sekolah. 
Hal yang penting bagi guru dalam tugasnya selaku pengajar di sekolah adalah harus memiliki persepsi yang baik tentang kepribadian dan pelaksanaan tugasnya. Secara khusus dalam model yang dikembangkan kompetensi profesional guru berkaitan dengan penguasaan, pengembangan dan pemanfaatan dalam hal menguasai materi, struktur, konsep dan pola pikir keilmuan yang mendukung mata pelajaran yang diampu, menguasai standar kompetensi dan kompetensi dasar mata pelajaran yang diampu, mengembangkan materi pembelajaran yang diampu secara kreatif, mengembangkan keprofesionalan secara berkelanjutan dengan melakukan tindakan reflektif dan memanfaatkan TIK untuk mengembangkan diri.

\section{Kesimpulan}

Kompetensi profesional guru merupakan kemampuanpenguasaanmateripelajaransecara luas dan mendalam, sehingga memungkinkan guru untuk membimbing peserta didik memenuhi standar kompetensi sesuai dengan Standar Nasional Pendidikan. Kompetensi guru berhubungan dengan kemampuan yang ditunjukkan seorang guru ketika melaksanakan peran dan fungsinya sebagai guru dalam proses pembelajaran di dalam kelas dengan berlandaskan kepada tanggung jawab, dedikasi, loyalitas dan kesungguhan dengan diimbangi oleh seluruh potensi yang dimiliki. Guru yang memiliki kompetensi akan bekerja melaksanakan fungsi dan tujuan sekolah khususnya dan tujuan pendidikan umumnya, sehingga dituntut untuk memiliki sejumlah karakteristik yang diharapkan. Hasil penelitian menunjukkan bahwa kompetensi profesional guru menunjukkan rata-rata 1,33 berada dalam kondisi tidak baik.Secara khusus jika dihubungkan dengan persepsi kompetensi profesional guru, dapat dilihat dari kompetensi tentang kepribadian dan kompetensi tentang melaksanakan tugas. Perspesi tentang kepribadian berhubungan dengan disiplin kerja, moralitas kerja, loyalitas, tanggung jawab dan hubungan manusiawi, sedangkan persepsi tentang kompetensi dalam melaksanakan tugas berhubungan dengan kesesuai kerja dan kelancaran melaksanakan tugas. Adapun saran yang dapat diberikan kepada Dinas Pendidikan Kabupaten Kendal maupun guru dalam meningkatkan kompetensi profesional adalah: untuk Dinas Pendidikan, yaitu: hendaknya memfasilitasi kebutuhan guru dalam meningkatkan kompetensi profesional guru, melakukan koordinasi dalam peningkatan kompetensi guru dengan pihak terkait, melakukan pemetaan kompetensi guru, sehingga jelas kebutuhannya dan peningkatan dilakukan secara kontinyu dengan jadwal yang jelas. Untuk guru, yaitu selalu aktif dalam meningkatkan kompetensi profesional baik secara mandiri maupun melalui kedinasan, bersedia untuk melakukan perubahan dan mau menularkan hasil peningkatan kompetensi kepada rekan sejawat.

\section{Daftar Pustaka}

Anugaerahwati, D. 2010. Model Pengembangan Kompetensi Profesional Guru Bahasa Inggris SMP di Kota Malang. Malang: Disertasi PPs Universitas Negeri Malang "Tidak Diterbitkan".

Danim. 2017. Metode Penelitian Kualitatif. Jakarta: Yayasan Obor Indonesia.

Dharma, A. 2009. Profesionalitas Guru: Tantangan Menghadapi Pendidikan Abad 21. Jakarta: Uhamka Press.

Faisal, S. 2010. Pengantar Penelitian Sosial. Surabaya: Usaha Nasional.

Moleong, J. L. 2007. Metodologi Penelitian Kualitatif. Bandung: Remaja Rosdakarya. Munandir. 2010. Pendekatan Penelitian dalam Pendidikan. Jakarta: Gramedia. 
Nasution. 2010. Pendekatan Baru dalam Penelitian. Bandung: Sinar Baru.

Natawidjaja, R. 2012. Profesionalisasi Tenaga Kependidikan: Guru dan Pekerjaannya. Depdiknas PPS UPI.

Rizal, S. 2012. Strategi Pembinaan Kemampuan Profesionalisme Guru Sekolah Dasar di Era Otonomi Daerah. Makalah: PPS UPI.

Sanchez, W. 2014. Experiences in social innovation: A platform for ethics through a scholl of engineering studies. Universidad Politecnica de Madrid, Madrid, Spain.

Sanusi, A. 2011. Studi Pengembangan Model Pendidikan Profesional Tenaga Kependidikan. Jakarta: Kemendikbud.

Satori, D. 2010. Manajemen Mutu Terpadu. Bandung: Rosdakarya.

Surapranata, S. 2009. Pendidikan dan Pelatihan dalam Peningkatan Kompetensi Guru. Jakarta: Uhamka Press.

Surya, M. 2013. Penilaian Kinerja Guru, Jakarta: Direktorat Tenaga Kependidikan.

Theeb, Muhaidat dan Al-Zboon. 2013. Profesional competencies among pre-service teacers in special educational from their perspectives. Faculty of Educational Sciences, University of Jordan, Yarmouk University and Hashemite University.

Usman, U. 2012. Menjadi Guru Profesional. Bandung: Rosdakarya. 